\title{
Threshold Chloride Concentration for Passivity Breakdown of Mg-Zn-Gd-Nd-Zr Alloy (EV31A) in Basic Solution
}

\author{
Jakraphan Ninlachart ${ }^{1} \cdot$ Krishnan S. Raja $^{1}$
}

Received: 12 August 2016/Revised: 17 December 2016/Published online: 14 February 2017

(C) The Chinese Society for Metals and Springer-Verlag Berlin Heidelberg 2017

\begin{abstract}
Mg}-\mathrm{Zn}-\mathrm{Gd}-\mathrm{Nd}-\mathrm{Zr}$ alloy (EV31A) is a heat-treatable magnesium $(\mathrm{Mg})$ cast alloy that can be used up to $200{ }^{\circ} \mathrm{C}$ for automobile and aerospace applications. This alloy has excellent mechanical properties (ultimate tensile strength: $280 \mathrm{MPa}$ at room temperature, and $\sim 230 \mathrm{MPa}$ at $200{ }^{\circ} \mathrm{C}$ ) and improved corrosion resistance. Electrochemical corrosion studies were conducted on this alloy under different heat treatment conditions in $0.1 \mathrm{M} \mathrm{NaOH}$ solution with the addition of 0-1000 ppm of chloride. The alloy showed excellent passivity in the $0.1 \mathrm{M} \mathrm{NaOH}$ solution. The passive potential range typically extended to more than $1.2 \mathrm{~V}_{\mathrm{Ag} / \mathrm{AgCl}}$. The transpassive potential was observed to be dependent on heat treatment condition of the alloy. More than $80 \mathrm{ppm}$ of chloride was required to induce passivity breakdown in any heat treatment condition. Peak aging at $200{ }^{\circ} \mathrm{C}$ for $16 \mathrm{~h}$ imparted better resistance for localized corrosion than other heat-treated conditions. The alloy in the as-received condition showed the highest passivation kinetics due to its smaller grain size that possibly increased the diffusion of reactive elements to form protective oxide. The passive film of the EV31A alloy showed n-type semiconductivity with a charge carrier density of $\sim 2 \times 10^{21} \mathrm{~cm}^{-3}$ with no chloride addition. The charge carrier density increased with chloride addition in the electrolyte which could be correlated with the susceptibility to localized corrosion.
\end{abstract}

KEY WORDS: Magnesium alloy; Corrosion; Passivation; Chloride

\section{Introduction}

Magnesium-based alloys have excellent strength-to-weight ratio, because of which they find applications in automobile, aerospace and biomedical devices and components. However, Mg alloys are limited by poor formability, texturing effect and creep resistance. Alloying with rare earth elements helps overcome some of these limitations. Microalloying with RE has been observed to improve the

Available online at http://link.springer.com/journal/40195

Jakraphan Ninlachart

nin16704@vandals.uidaho.edu

1 Chemical and Materials Engineering, University of Idaho, Moscow, ID 83844-1021, USA ductility and weaken the texturing effect [1, 2]. $\mathrm{Zr}$ is added as alloying element in $\mathrm{Al}$-free $\mathrm{Mg}$ alloys to mitigate the detrimental behavior of impurities such as $\mathrm{Fe}, \mathrm{Ni}$ and $\mathrm{Co}$ which otherwise will form cathodic intermetallic compounds and increase the corrosion attack. $\mathrm{Zr}$ also improves the mechanical properties by refining the grains [3, 4]. Alloying with RE also improves the high-temperature tensile strength and creep resistance [5]. Alloy EV31A (also known as Elektron 21 from Magnesium Elektron N.A Inc.) was recently introduced as an alternate to the widely known WE43 alloy owing to its low cost, easy castability due to the absence of yttrium, and enhanced corrosion resistance [6]. The corrosion rate of the EV31A alloy has been reported to be $10-30 \mathrm{~m} / \mathrm{y}$ based on the ASTM B117 salt spray test [7].

EV31A nominally has (in wt $\%$ ) $0.2 \%-0.5 \% \mathrm{Zn}, 2.6 \%-$ $3.1 \% \mathrm{Nd}, 1.0 \%-1.7 \% \mathrm{Gd}$ and saturated amount of $\mathrm{Zr}$ as 
alloying additions. $\mathrm{Zr}$ has a calculated solubility of about 0.76 at.\% in liquid $\mathrm{Mg}$ and about 0.2 at.\% at $400{ }^{\circ} \mathrm{C}$ [8]. The maximum solid solubility of $\mathrm{Zn}$ at eutectic temperature is 2.4 at. $\%$ and decreases to about 0.1 at. $\%$ at room temperature. The identified secondary phases in the $\mathrm{Mg}-\mathrm{Zn}-\mathrm{Zr}$ system are $\mathrm{MgZn}, \mathrm{Mg}_{7} \mathrm{Zn}_{3}, \mathrm{Zn}_{2} \mathrm{Zr}_{3}, \mathrm{ZnZr},(\mathrm{Zn}, \mathrm{Mg})_{2} \mathrm{Zr}$ and $\mathrm{Zn}_{2}(\mathrm{Mg}, \mathrm{Zr})$ [9]. Out of these, $\mathrm{Zn}_{2} \mathrm{Zr}_{3}$ phase is most likely present in the EV31A alloy [10].

The terminal solid solution of $\mathrm{Nd}$ in $\mathrm{Mg}$ is considered to be 0.7 at. \% at its eutectic temperature $(822 \mathrm{~K})$, and the secondary phases that are in equilibrium with the solid solution are $\mathrm{Mg}_{41} \mathrm{Nd}_{5}, \mathrm{Mg}_{3} \mathrm{Nd}, \mathrm{Mg}_{2} \mathrm{Nd}, \mathrm{MgNd}$ and $\mathrm{Mg}_{12}$ $\mathrm{Nd}$ [11]. The $\mathrm{Mg}_{2} \mathrm{Nd}$ phase is considered to be metastable since only the quenched sample contained this phase and not the annealed ones [12]. The terminal solid solubility of $\mathrm{Gd}$ in $\mathrm{Mg}$ is reported to be $23.49 \mathrm{wt} \%$ at $548{ }^{\circ} \mathrm{C}$ (eutectic temperature), and the secondary phases of the $\mathrm{Mg}-\mathrm{Gd}$ binary system are $\mathrm{Mg}_{5} \mathrm{Gd}, \mathrm{Mg}_{3} \mathrm{Gd}, \mathrm{Mg}_{2} \mathrm{Gd}$ and $\mathrm{MgGd}$. Addition of $\mathrm{Nd}$ and $\mathrm{Gd}$ together helps improve the age hardening response as the solubility of $\mathrm{Gd}$ is reduced with the incorporation of $\mathrm{Nd}$ [13]. Zinc is also considered to enhance the age hardening response and creep strength of $\mathrm{Mg}-\mathrm{Gd}$ alloys [14]. In a Mg-Nd-Gd system, addition of $\mathrm{Zn}$ can delay the overaging process at $250{ }^{\circ} \mathrm{C}$ and increase the hardness [13].

Addition of $\mathrm{Zn}$ to $\mathrm{Mg}-\mathrm{Nd}-\mathrm{Gd}-\mathrm{Zr}$ system was observed to increase the corrosion resistance when the $\mathrm{Zn}$ content was around $0.2 \%$ exfoliation-type corrosion attack observed and with $0.75 \% \mathrm{Zn}$ the corrosion occurred by preferential dissolution of zinc zirconide-type coarse precipitates [13]. Good corrosion resistance was observed when the $\mathrm{Zn}$ content was in the range of $0.2 \%-0.55 \%$ and Gd was $<1.75 \%$.

The EV31A alloy can be solution-heat-treated at $525{ }^{\circ} \mathrm{C}$ for $8 \mathrm{~h}$ followed by quenching in warm water at $60-80{ }^{\circ} \mathrm{C}$. After quenching, the alloy can be artificially aged in the temperature range of $150-300{ }^{\circ} \mathrm{C}$ for different time periods to achieve desired results. The precipitation reactions occurring during the aging process are reported to follow the sequence of $\alpha-\mathrm{Mg} \rightarrow \beta^{\prime \prime} \rightarrow \beta^{\prime} \rightarrow \beta \quad\left(\mathrm{Mg}_{3-}\right.$ $\mathrm{RE}) \rightarrow \mathrm{Mg}_{41} \mathrm{RE}_{5}$ [15]. The $\beta^{\prime \prime}$ phase has a platelet morphology of $8 \mathrm{~nm}$ long and $2 \mathrm{~nm}$ thick coherent with the matrix under peak hardening condition [16]. The $\beta^{\prime}$ phase is metastable and semicoherent with matrix with spherical morphology. The lattice structure of the $\beta^{\prime}$ phase is bodycentered orthogonal. The stable $\beta$ phase $\left(\mathrm{Mg}_{3} \mathrm{RE}\right)$ has a fcc structure [16].

The composition of $\beta^{\prime \prime}$ in EV31A has not been clearly reported due to its nanoscale size and limitations in imaging of $\mathrm{Mg}$ under ion field [17]. Using 3-D atom probe, Nie and coworkers [17] reported that the composition of ordered G.P. zone precipitates in a Mg-RE-Zn-Zr alloy was 3.2 at. $\% \mathrm{Nd}, 1$ at. $\% \mathrm{Ce}$ and 1.2 at.\% $\mathrm{Zn}$. The composition of $\beta^{\prime}$ phase of $\mathrm{Mg}-\mathrm{Nd}-\mathrm{Gd}$ alloys was reported to follow the stoichiometry of $\mathrm{Mg}_{6} \mathrm{Nd}$ [18]. Increasing the $\mathrm{Nd}: \mathrm{Zn}$ ratio increased the $\mathrm{Nd}$ content of the $\beta^{\prime}$ phase precipitates. When the $\mathrm{Nd}: \mathrm{Zn}$ ratio was $2: 1$, the precipitates were of $\mathrm{Mg}_{5} \mathrm{Nd}$ type and when $\mathrm{Nd}: \mathrm{Zn}$ ratio was $1: 1$, the $\beta^{\prime}$ phase was of $\mathrm{Mg}_{9} \mathrm{Nd}$ type. This composition is different from that reported by Kielbus et al. [15].

Most of the corrosion studies of Mg-RE alloys have been carried out in chloride-containing solutions that are mimicking either marine or biological environment $[19,20]$. Scully and coworkers compiled open-circuit potentials (OCPs) or corrosion potentials $\left(E_{\text {corr }}\right)$ of different $\mathrm{Mg}$ alloys exposed to different concentrations of $\mathrm{NaCl}$ solutions $(0.01-5 \mathrm{M})$ in near neutral $\mathrm{pH}$ conditions and observed that $\mathrm{Mg}-\mathrm{RE}$ alloys showed the most negative corrosion potentials or similar to the potentials of pure $\mathrm{Mg}$, when the total RE content was $<2.75 \mathrm{wt} \%$ [21]. Increasing the chloride concentration shifts the OCP to a more cathodic potential. The alloy WE43 shows a more negative OCP (between -1.75 and $-1.85 \mathrm{~V}_{\mathrm{SCE}}$ ) than that of pure $\mathrm{Mg}\left(-1.6\right.$ to $\left.-1.72 \mathrm{~V}_{\mathrm{SCE}}\right)$ in the neutral chloride solutions. The $\mathrm{Mg}_{3} \mathrm{Nd}$ intermetallic has a relatively less cathodic OCP $\left(-1.55 \mathrm{~V}_{\mathrm{SCE}}\right)$ in $0.1 \mathrm{M} \mathrm{NaCl}$ [22]. Increasing the $\mathrm{pH}$ increases the OCP. The more active corrosion potentials observed in $\mathrm{Mg}-\mathrm{RE}$ alloys than those of pure $\mathrm{Mg}$ are counter-institutive to the well-documented "reactive element effect" of rare earth elements that enhances the protective characteristics of the surface oxide [23]. Most of the available reports on corrosion of $\mathrm{Mg}-\mathrm{RE}$ alloys pertain to cast structures. Recently Birbilis and coworkers investigated the influence of low levels of $\mathrm{Zn}, \mathrm{Gd}$, and $\mathrm{Zr}$ in $\mathrm{Mg}$ for wrought applications [24]. They observed that addition of $\mathrm{Zr}$ and $\mathrm{Gd}$ generally resulted in enhanced kinetics of cathodic reaction in $\mathrm{Mg}-0.4 \mathrm{Zn}-0.8 \mathrm{Ca}$ alloy, and reduced the anodic reaction kinetics. Overall, the investigated $\mathrm{Mg}$ alloys showed higher corrosion rates than pure $\mathrm{Mg}$, because of higher cathodic kinetics, and ennobled corrosion potentials.

Passivation of $\mathrm{Mg}$ alloys has been observed in high alkaline solutions. Ismail and Virtanen [25] observed large fluctuations in OCP (between -1.6 and $-0.55 \mathrm{~V}_{\mathrm{SCE}}$ ) of $\mathrm{AZ}$ 31 alloy in $0.5 \mathrm{M} \mathrm{KOH}$. The potential shifts were cyclic in nature and were attributed to the formation of passive film and subsequent dissolution. Similar type of OCP fluctuations was observed in pure $\mathrm{Mg}$ exposed to $1 \mathrm{M} \mathrm{NaOH}$ solution by Taheri and Kish [26]. These authors proposed that hydration of the initially formed crystalline $\mathrm{MgO}$ layer caused stress induced localized breakdown of the surface film on Mg. During the film formation process, the OCP shifted to less negative values. The breakdown of the film caused the OCP to move back to its original values, and subsequent repair of the film caused ennoblement of the OCP. Li et al. [27] investigated passivation behavior of 
AZ31B die cast $\mathrm{Mg}-\mathrm{Al}-\mathrm{Zn}-\mathrm{Mn}$ alloy in alkaline $(\mathrm{NaOH})$ solutions with $\mathrm{pH} 10-14$. These authors found that the thickness of the surface layer was different on different phases of the specimen when exposed to $\mathrm{pH} \geq 13$ solutions, whereas uniform thickness of the film was noticed on all the phases in the entire surface when tested in $\mathrm{pH} 12$ solution. The reduction in $\mathrm{pH}$ to 11 caused galvanic corrosion between different phases.

Song and Unocic [28] investigated anodic surface films formed on $\mathrm{Mg}$ in $\mathrm{Mg}(\mathrm{OH})_{2}$-saturated solution. They observed intensive hydrogen evolution even at the potentials more positive than the equilibrium hydrogen evolution potential due to formation of univalent $\mathrm{Mg}$ ions and subsequent reaction with water. The surface film became more porous due to intensified anodic $\mathrm{H}_{2}$ evolution. Cao et al. [29] critically reviewed the literature on the passivation of $\mathrm{Mg}$ alloys and recommended future research directions. The review discussed different scenarios of rendering passivity in $\mathrm{Mg}$, such as kinetically induced passivation by alloying with $\mathrm{Cr}, \mathrm{Ti}, \mathrm{Al}, \mathrm{Ni}, \mathrm{Zr}$, etc., passivation in special environments, design of heat treatments for passivation and microstructural modifications by processing conditions. Recently, Song et al. [30] prepared Mg-Ti alloy thin films by magnetron sputtering and studied their passivation behavior in $0.1 \mathrm{wt} \% \mathrm{NaCl}$ solution saturated with $\mathrm{Mg}(\mathrm{OH})_{2}$. They observed that about 51 at.\% of $\mathrm{Ti}$ was required to induce passivity on the $\mathrm{Mg}-\mathrm{Ti}$ alloys. At a lower addition of $\mathrm{Ti}$, the passivation was not effective.

Yao et al. [31] investigated the passivation behavior of $\mathrm{Mg}-\mathrm{Y}$ alloys in alkaline chloride solutions and observed incorporation of $\mathrm{Y}_{2} \mathrm{O}_{3}$ in the passive film which enhanced passivity. Pinto et al. [32, 33] studied passive behavior of Mg-Zr-RE alloys, such as ZK31, EZ33 and WE54, in alkaline media with and without chloride addition and in borate buffer solution. The passive film in alkaline solution consisted of an outer $\mathrm{Mg}(\mathrm{OH})_{2}$-type layer and an inner $\mathrm{MgO}$ layer without the presence of alloying elements. On the other hand, in borate buffer solution ( $\mathrm{pH}$ 9.2), an amorphous yttrium oxide/hydroxide thick layer was observed that imparted higher corrosion resistance to the WE54 alloy. Alloying with RE was observed to improve the corrosion resistance when the RE was in the solution. When RE segregated along grain boundaries as a secondary phase, microgalvanic effect was noticed.

The foregoing discussion on the corrosion literature of $\mathrm{Mg}-\mathrm{RE}$ alloys mostly pertains to cast structures in the neutral chloride solutions. The effect of wrought microstructures (that will have much smaller and uniformly distributed secondary phase particles) on the corrosion behavior has not been investigated in detail. The typically used $0.1 \mathrm{M} \mathrm{NaCl}$ that mimicks the marine atmosphere may be too aggressive to understand the effect of microstructures on the corrosion behavior of $\mathrm{Mg}-\mathrm{RE}$ alloys.
Furthermore, the passivation behavior of EV31A has not been investigated in detail to the best of the authors' knowledge. In this study, the electrochemical passivation behavior of EV31A under different heat-treated conditions was evaluated to understand the effect of aging microstructure and chloride concentration in $0.1 \mathrm{M} \mathrm{NaOH}$ solution $(\mathrm{pH} 13.5)$ on the passivity breakdown at room temperature. The strong alkaline solution was employed because $\mathrm{Mg}$ can form a stable surface film at $\mathrm{pH}>11$ according to the potential $\mathrm{pH}$ equilibrium diagram of $\mathrm{Mg}$ $\mathrm{H}_{2} \mathrm{O}$ [34]. Therefore, this work is fundamental in nature.

\section{Experimental}

The material used in this investigation was $\mathrm{Mg}-\mathrm{Zn}-\mathrm{Gd}-$ $\mathrm{Nd}-\mathrm{Zr}$ alloy (EV31A), a 16-mm-thick plate provided by Magnesium Elektron N.A Inc. It was cut into $1.5 \mathrm{~cm} \times 2.5 \mathrm{~cm} \times 0.3 \mathrm{~cm}$ coupons. The as-received coupons were solution heat-treated at $525{ }^{\circ} \mathrm{C}$ for $8 \mathrm{~h}$ and quenched in water. Aging treatments were carried out at $200{ }^{\circ} \mathrm{C}$ for 16 and $100 \mathrm{~h}$ and then cooled in air. The specimens were ground with $\mathrm{SiC}$ paper up to 600 grit and cleaned with methanol and dried in air just before corrosion test. For microstructural observation and microhardness test, the specimens were ground with $\mathrm{SiC}$ paper up to 1200 grit and 1-micron diamond suspension and then cleaned with methanol and dried. Etching was carried out to reveal the grain boundaries of tested specimens with glycol etchant containing $10 \mathrm{ml} \mathrm{HNO}_{3}, 24 \mathrm{ml}$ water, $75 \mathrm{ml}$ ethylene glycol. The optical microscopy on the etched specimens was conducted using an OLYMPUS PMG3 optical microscope. Vickers hardness was measured using a microhardness tester (Leco, LM100 from Leco) and a load of $10 \mathrm{~g}$. The reported values are average of at least ten readings in each specimen.

The electrochemical measurements were conducted by using 3-electrode flat PTFE electrochemical cell with a Pt wire spiral $\left(2.5 \mathrm{~cm}^{2}\right.$ surface area) as counter electrode and $\mathrm{KCl}$-saturated $\mathrm{Ag} / \mathrm{AgCl}(199 \mathrm{mV}$ vs. SHE) as reference electrode and a potentiostat (VersaSTAT MC, and VersaStudio software version 2.42.3 from Princeton Applied Research). The exposed surface area of specimen was $1 \mathrm{~cm}^{2}$. The electrolytes were $0.1 \mathrm{M} \mathrm{NaOH}(\mathrm{pH} 13.5)$ with different chloride concentrations $(0,80,100,200,500$ and $1000 \mathrm{ppm}$ $\mathrm{Cl}^{-}$in the form of $\mathrm{NaCl}$ ). The cyclic polarization was performed at $0-2.5 \mathrm{~V}$ vs OCP at a scan rate of $1 \mathrm{mV} / \mathrm{s}$. It should be noted that the apex potential is much higher than the equilibrium potential of oxygen evolution (water stability limit), and may not be very relevant to practical service conditions. However, such a high potential was found to be necessary for evaluating the passivity breakdown under different heat treatment conditions. No correction was 
carried out to account for the iR drop in the system, and thus, the effect of solution conductivity was unknown. The potential scans were reversed at $2.5 \mathrm{~V}_{\mathrm{Ag} / \mathrm{AgCl}}$, or when the transpassive current density was reached $1 \mathrm{~mA} / \mathrm{cm}^{2}$. The potentiostatic tests were conducted for $3600 \mathrm{~s}$ at the middle of the passivation range. Electrochemical impedance spectroscopy (EIS) measurements were carried out under potentiostatic condition by applying the passivating potential and superimposing an $\mathrm{AC}$ signal of $10 \mathrm{mV}$, and scanning the frequency from $100 \mathrm{kHz}$ down to $10 \mathrm{mHz}$. MottSchottky measurements were carried out at a frequency of $316 \mathrm{~Hz}$ by scanning the potential of the specimens from the middle of the passivation range to OCP at $50 \mathrm{mV}$ steps.

\section{Results and Discussion}

\subsection{Microstructural Characterization}

Figure 1a-d illustrates the optical microstructure of the specimens in different heat treatment conditions. Figure 1a shows the as-received microstructure of the $\mathrm{T}-\mathrm{S}$ (transverse- short transverse) orientation. Banding and texturing across the thickness of the plate with fine grain size can be observed. The X-ray diffraction (XRD) pattern of the as-received specimen has several minor peaks associated with secondary phases such as $\mathrm{Mg}_{12} \mathrm{Nd}, \mathrm{Mg}_{3} \mathrm{RE}$ and $\mathrm{Mg}_{41} \mathrm{Nd}_{5}$, as shown in Fig. 2a. Solution treatment considerably reduced the banding and texturing and resulted in grain growth with an average grain size of about $30 \mu \mathrm{m}$. The presence of intermetallic phases within grains and along grain boundaries can be observed as shown in Fig. 1b. The undissolved secondary phase particles have been identified as $\mathrm{Mg}_{12} \mathrm{Nd}$ by other investigators [35]. The XRD results shown in Fig. 2a support the presence of $\mathrm{Mg}_{x} \mathrm{RE}$ phase in the solution-treated alloy. The microstructure of the peak-aged specimen is illustrated in Fig. 1c.

Since the peak aging can result in precipitation of nanoscale $\beta^{\prime \prime}$ phase that is coherent with the matrix, the optical microstructure of the peak-aged sample cannot be significantly different from that of the solution heat-treated (ST) specimen. The XRD pattern of the peak-aged (PA) specimen is more or less similar to that of the ST. Figure $1 \mathrm{~d}$ shows the microstructure of the overaged (OA)
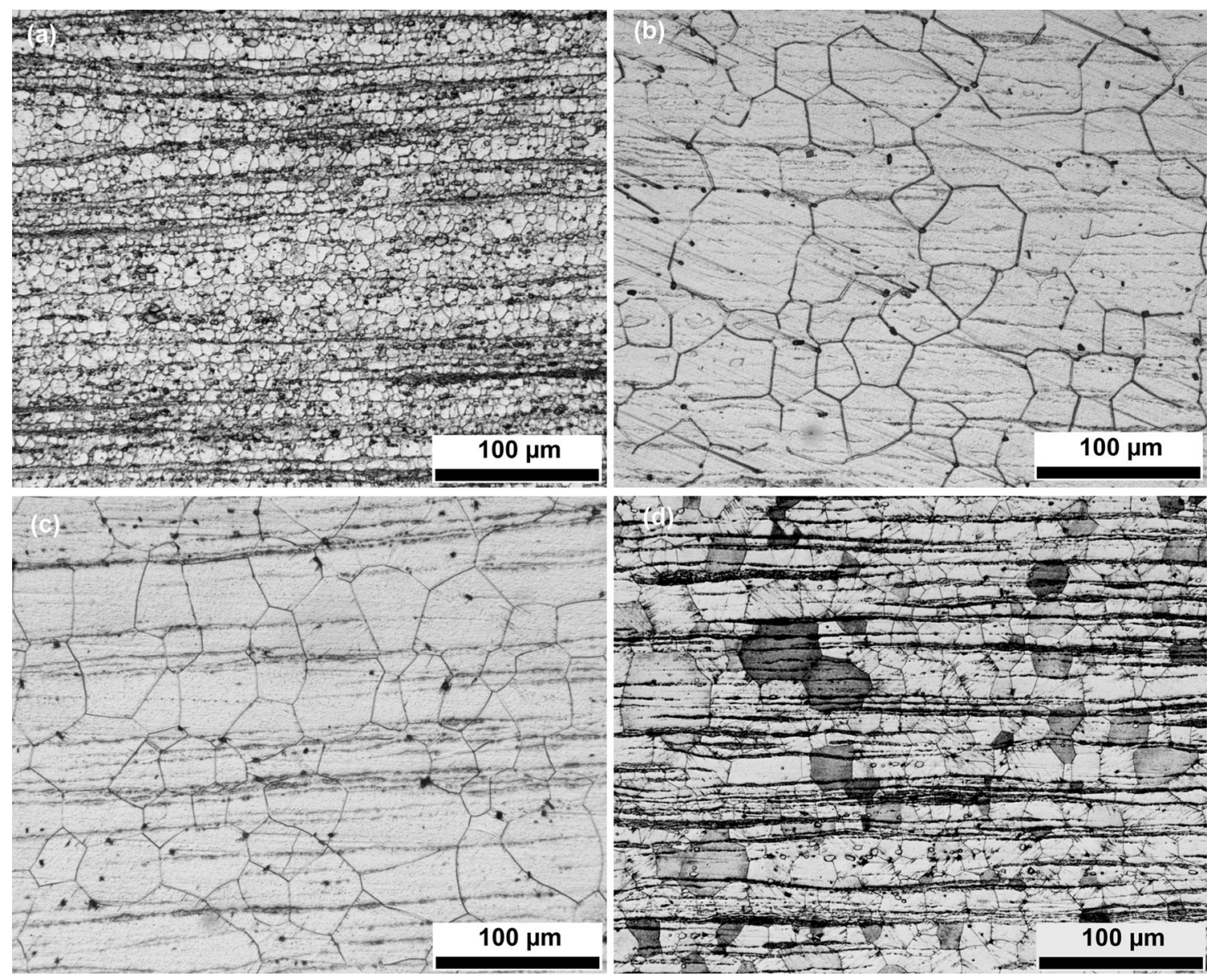

Fig. 1 Optical microstructures of EV31A in different heat treatment conditions: a as-received, b solution heat-treated, $\mathbf{c}$ peak-aged $\left(200{ }^{\circ} \mathrm{C}\right.$, $16 \mathrm{~h})$, d overaged $\left(200^{\circ} \mathrm{C}, 100 \mathrm{~h}\right)$ 

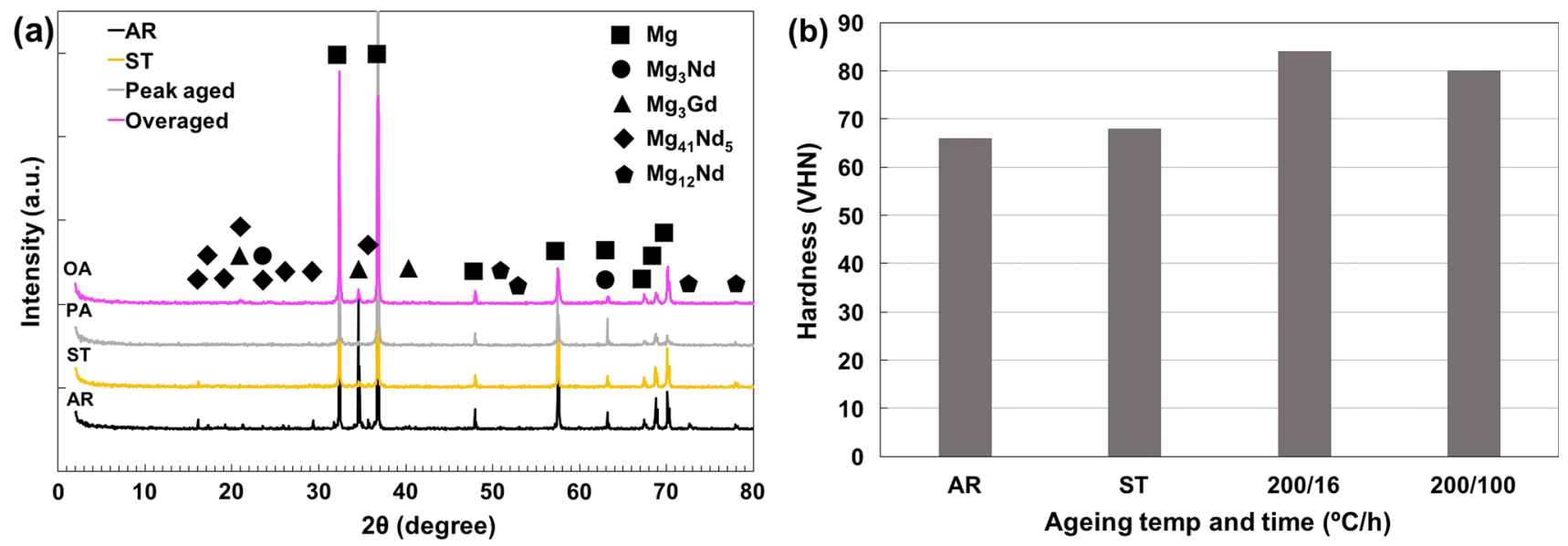

Fig. 2 a XRD patterns of EV31A in different heat treatment conditions, $\mathbf{b}$ Vickers hardness of EV31A in different heat treatment conditions. AR as-received, $S T$ solution heat-treated, 200/16: peak-aged (PA) at $200{ }^{\circ} \mathrm{C}$ for $16 \mathrm{~h}, 200 / 100$ overaged (OA) at $200{ }^{\circ} \mathrm{C}$ for $100 \mathrm{~h}$

specimen. Cellular-type precipitates nucleate at the grain boundaries. Some grains that were etched dark are considered to have a high volume fraction of the cellular-type $\beta$ phase $\left(\mathrm{Mg}_{3} \mathrm{RE}\right)$ precipitation within the grains. The darketched bands running across grains suggest preferential precipitation of $\beta$ phase on these highly strained locations that contained a high density of dislocations. The XRD pattern indicates the presence of $\mathrm{Mg}_{3}$ RE-type $\beta$ phase in the OA sample.

Figure $2 b$ illustrates the Vickers hardness of the specimens. Almost similar hardness was observed for the specimens in the as-received (AR) and solution heat-treated (ST) conditions. Heating at $200{ }^{\circ} \mathrm{C}$ for $16 \mathrm{~h}$ (T6 condition) is considered to be peak aging as the hardness reached the highest value $84 \mathrm{VHN}\left(\mathrm{kgf} / \mathrm{mm}^{2}\right)$. Aging at $200{ }^{\circ} \mathrm{C}$ for $100 \mathrm{~h}$ resulted in hardness of $80 \mathrm{VHN}$. The peak-aging and overaging conditions are categorized based on their microstructures and hardness values. Similar results have been reported by other investigators [15].

\subsection{Cyclic Polarization Behavior}

Figure $3 \mathrm{a}$ illustrates the cyclic polarization plots of the EV31A specimens in $0.1 \mathrm{M} \mathrm{NaOH}$ solution without chloride addition. The $\mathrm{ST}$ specimen showed the most active corrosion potential, and the AR specimen showed the least active corrosion potential. The variations in the OCP could be due to the differences in the microstructures that show different cathodic and anodic reaction kinetics. Based on the mixed potential theory [36], more active OCP values can be anticipated when the exchange current density for cathodic reaction is lower or the cathodic Tafel slope is steeper for a given anodic reaction kinetics. Alternately, for a given cathodic reaction kinetics, lower corrosion potential will be observed when the exchange current density for the anodic reaction is higher or the Tafel slope of the anodic reaction is shallower. Since better passivation behavior is expected when the RE and other alloying elements are in solid solution, steeper Tafel slope of anodic reaction is expected. Chu and Marquis reported steeper cathodic Tafel slope and lower exchange current density for the solution-treated WE43 alloy than that of peak-aged condition [37]. Based on the foregoing discussion, it should be noted that lower activity for the cathodic reaction could be the reason for the more negative OCP of the solutiontreated specimens. Both PA and OA specimens showed almost similar OCP values between the OCPs of the ST and AR specimens. It is interesting to note that ST, PA and OA specimens showed almost similar passive current densities in the range of $2.67-4.1 \mu \mathrm{A} / \mathrm{cm}^{2}$.

The passive current density was the lowest for the ST condition at $2.67 \mu \mathrm{A} / \mathrm{cm}^{2}$, and it increased for the aging condition, while the OA specimen showed $4.11 \mu \mathrm{A} / \mathrm{cm}^{2}$. The AR specimen showed an even higher current density $\left(7-10 \mu \mathrm{A} / \mathrm{cm}^{2}\right)$ which increased with anodic polarization indicating possible presence of a highly disordered or defective passivation layer. Passivation of the specimens was observed between $-1 \mathrm{~V}$ and $+1.6 \mathrm{~V}_{\mathrm{Ag} / \mathrm{AgCl}}$. The transpassive potentials were not significantly different among the different heat treatment conditions. When the potential scan was reversed after reaching the transpassive condition, a small hysteresis was observed as the reverse scan did not exactly trace the forward current profile. The cross-over potential of the reverse scan on the forward scan curve is considered generally as pitting protection potential. However, in the $0.1 \mathrm{M} \mathrm{NaOH}$ without any chloride addition no pitting is expected to occur. All the other specimens in chloride-containing solutions showed hysteresis and breakdown of passivity. In stainless alloys, such as $\mathrm{Ni}-\mathrm{Cr}-\mathrm{Mo}$ alloys, the transpassive current could be associated with oxygen evolution reaction as given in reaction (1) and not the metal dissolution [38]. 

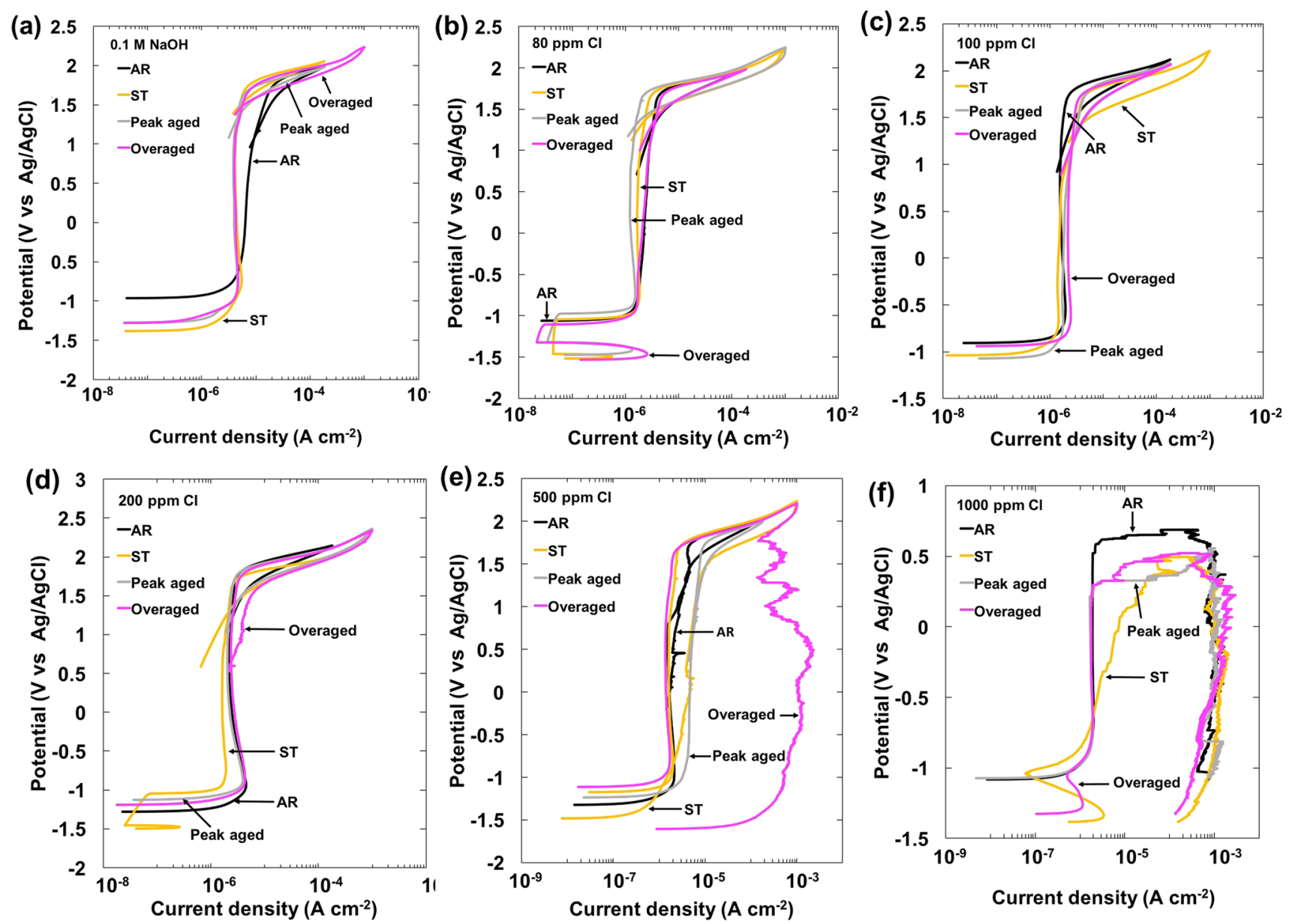

Fig. 3 Cyclic polarization results of EV31A specimens in different heat-treated conditions in $0.1 \mathrm{M} \mathrm{NaOH}$ with different chloride additions: a 0 ppm $\mathrm{Cl}^{-}$, b $80 \mathrm{ppm} \mathrm{Cl}^{-}$, c $100 \mathrm{ppm} \mathrm{Cl}^{-}$, d $200 \mathrm{ppm} \mathrm{Cl}^{-}$, e $500 \mathrm{ppm} \mathrm{Cl}^{-}$, f $1000 \mathrm{ppm} \mathrm{Cl}^{-}$

$4 \mathrm{OH}^{-} \rightarrow \mathrm{O}_{2}+2 \mathrm{H}_{2} \mathrm{O}+4 \mathrm{e}^{-}$

In addition to the oxygen evolution, the other possible transpassive reactions of $\mathrm{Mg}$ in alkaline solution without chloride are given as follows:

$$
\begin{aligned}
& 2 \mathrm{Mg}+8 \mathrm{OH}^{-} \rightarrow 2 \mathrm{MgO}+\mathrm{O}_{2}+4 \mathrm{H}_{2} \mathrm{O}+8 \mathrm{e}^{-}, \\
& \mathrm{MgO}+\mathrm{H}_{2} \mathrm{O} \rightarrow \mathrm{Mg}(\mathrm{OH})_{2}, \\
& \mathrm{Nd}(\mathrm{OH})_{3}+\mathrm{OH}^{-} \rightarrow \mathrm{NdO}_{2}+2 \mathrm{H}_{2} \mathrm{O}+2 \mathrm{e}^{-}, \\
& 2 \mathrm{NdO}_{2}+3 \mathrm{H}_{2} \mathrm{O} \rightarrow 2 \mathrm{Nd}(\mathrm{OH})_{3}+\frac{1}{2} \mathrm{O}_{2}, \\
& \mathrm{Zn}+4 \mathrm{OH}^{-} \rightarrow \mathrm{ZnO}_{2}^{2-}+2 \mathrm{H}_{2} \mathrm{O}+2 \mathrm{e}^{-} \\
& \mathrm{Zr}+5 \mathrm{OH}^{-} \rightarrow \mathrm{HZrO}_{3}^{-}+2 \mathrm{H}_{2} \mathrm{O}+4 \mathrm{e}^{-}
\end{aligned}
$$

It is documented that the passivity of $\mathrm{Mg}-\mathrm{RE}$ alloys is attributed to the formation of $\mathrm{MgO}$ and $\mathrm{Mg}(\mathrm{OH})_{2}$ layers on the surface with incorporation of RE oxide/hydroxide [32]. No surface analysis of the passive film was carried out in this work to support the incorporation of rare earth oxide in the surface layer. It is simply a hypothesis based on the data presented in [32]. At the transpassive conditions (when the polarization potential is sufficiently high for oxygen evolution), chemical dissolution of the cations from the passive layer could occur aided by oxygen evolution reaction. This dissolution weakens the passive layer, and a series of reactions given in (2a)-(5) are postulated to take place.

The reactions (2a) and (2b) are the regular passive film formation reactions, and those also occur in the transpassive condition at the sites disrupted by the oxygen evolution reaction. Reaction (3a) is oxidation of $\mathrm{Nd}^{3+}$ to $\mathrm{Nd}^{4+}$ which is not stable in aqueous electrolyte and therefore can revert back to $\mathrm{Nd}^{3+}$ by evolving oxygen [39]. The oxidation reactions of the alloying elements proposed through reactions (2a)-(5) in combination with the oxygen evolution reaction could result in hysteresis. During the reverse scan, less potential was required to induce the same current as compared to the forward scan. This could be due to decrease in the resistivity of the passive layer. The resistivity is influenced by the charge carrier densities of the passive layer. Introduction of Schottky- or Frenkel-type 
Table 1 Cyclic polarization results of EV31A specimens in different heat-treated conditions in $0.1 \mathrm{M} \mathrm{NaOH}$

\begin{tabular}{lllll}
\hline Sample & $\begin{array}{l}\text { OCP } \\
(\mathrm{V} \text { vs } \mathrm{Ag} / \mathrm{AgCl})\end{array}$ & $\begin{array}{l}E_{\text {Transpassive }} \\
(\mathrm{V} \text { vs } \mathrm{Ag} / \mathrm{AgCl})\end{array}$ & $\begin{array}{l}E_{\text {Cross over }} \\
(\mathrm{V} \text { vs } \mathrm{Ag} / \mathrm{AgCl})\end{array}$ & $\begin{array}{l}\text { Passive current density } \\
\left(\mu \mathrm{A} / \mathrm{cm}^{2}\right)\end{array}$ \\
\hline AR & -1.03 & 1.67 & 1.07 & 7.00 \\
ST & -1.50 & 1.73 & 1.52 & 2.67 \\
Peak aged & -1.20 & 1.52 & 1.31 & 3.90 \\
Overaged & -1.21 & 1.58 & 1.47 & 4.11 \\
\hline
\end{tabular}

Table 2 Cyclic polarization results of EV31A specimens in different heat-treated conditions in $80 \mathrm{ppm} \mathrm{Cl}^{-}$solution

\begin{tabular}{lllll}
\hline Sample & OCP & $\begin{array}{l}E_{\text {Transpassive }} \\
(\mathrm{V} \text { vs } \mathrm{Ag} / \mathrm{AgCl})\end{array}$ & $\begin{array}{l}E_{\text {Cross over }} \\
(\mathrm{V} \text { vs Ag/AgCl })\end{array}$ & $\begin{array}{l}\text { Passive current density } \\
\left(\mu \mathrm{Ag} / \mathrm{cm}^{2}\right)\end{array}$ \\
\hline AR & -1.66 & 1.64 & 1.27 & 2.50 \\
ST & -1.57 & 1.61 & 1.37 & 1.66 \\
Peak aged & -1.55 & 1.58 & 1.29 & 1.21 \\
Overaged & -1.57 & 1.62 & 1.38 & 2.20 \\
\hline
\end{tabular}

defects in the passive layer affects the electronic conductivity during polarization and therefore causes hysteresis in the cyclic polarization. Alternately, the increase in surface area due to transpassive dissolution of $\mathrm{Mg}$ and other alloying elements could also be attributed to the minor hysteresis observed in the cyclic polarization plot.

Table 1 summarizes the cyclic polarization results in $0.1 \mathrm{M} \mathrm{NaOH}$. The cross-over potentials of ST, PA and OA specimens are $1.52,1.31$ and $1.47 \mathrm{~V}_{\mathrm{Ag} / \mathrm{AgCl}}$, respectively. Below the cross-over potential, the passive current density of the reverse scan is much lower than that of the forward scan. The AR specimen shows a cross-over potential of $1.07 \mathrm{~V}_{\mathrm{Ag} / \mathrm{AgCl}}$. This result indicates that anodic polarization in the transpassive range introduced a high density of defects in the passive layer of the as-received specimen, and it took a long time to recover or anneal out the defects during the reverse scan. In other words, the passive layer of the AR condition was less stable perhaps due to the banded and the textured microstructures of the substrate.

Figure $3 \mathrm{~b}$ shows the cyclic polarization of the specimens in $80 \mathrm{ppm} \mathrm{Cl}^{-}$-containing $0.1 \mathrm{M} \mathrm{NaOH}$ solution. The AR specimen has a higher OCP than other specimens. The polarization curves of PA and OA specimens indicate two different anodic processes in the potential window from -1.6 to $-0.8 \mathrm{~V}_{\mathrm{Ag} / \mathrm{AgCl}}$.

Polarization curves with an inflection point or a two-step process have been reported for ZK31 alloy [33] and Mg [40]. Natta attributed the current peak at the lower potential to the formation of univalent $\mathrm{Mg}$

$\mathrm{Mg} \rightarrow \mathrm{Mg}^{+}+\mathrm{e}^{-} \quad E^{0}=-2.28 \mathrm{~V}_{\mathrm{Ag} / \mathrm{AgCl}}$,

and the second oxidation shoulder at the slightly higher potential to the reaction of forming divalent $\mathrm{Mg}$ ions:
$\mathrm{Mg} \rightarrow \mathrm{Mg}^{2+}+2 \mathrm{e}^{-} \quad E^{0}=-1.36 \mathrm{~V}_{\mathrm{Ag} / \mathrm{AgCl}}$.

It should be noted that no direct evidence of the formation of $\mathrm{Mg}^{+}$has been reported although the involvement of $\mathrm{Mg}^{+}$ in the anodic dissolution in film broken areas has successfully explained numerous electrochemical corrosion phenomena of $\mathrm{Mg}$ alloys. In case of the AR specimen, the oxidation shoulder of formation of monovalent $\mathrm{Mg}$ was not revealed because the OCP was more positive than the Flade potential. Addition of $80 \mathrm{ppm} \mathrm{Cl}^{-}$did not affect the passive current density and the transpassive potentials as summarized in Table 2. The pitting protection potentials recorded for the specimens in $80 \mathrm{ppm} \mathrm{Cl}^{-}$were similar to their counterparts in the $0.1 \mathrm{M} \mathrm{NaOH}$ solution without chloride addition. These results indicated that the EV31A alloy can be safely used in $80 \mathrm{ppm} \mathrm{Cl}^{-}$-containing environment of $\mathrm{pH} 13$. It should be noted that the high $\mathrm{pH}$ environment may not represent a real service condition. However, such a study presented here helps fundamentally understand the passivity nature of $\mathrm{Mg}-\mathrm{RE}$ alloys.

Figure $3 \mathrm{c}-\mathrm{f}$ shows the cyclic polarization results in $0.1 \mathrm{M} \mathrm{NaOH}$ with the addition of $100,200,500$ and $1000 \mathrm{ppm}$ chloride. Increasing the chloride additions did not increase the passive current density. The maximum passive current density recorded was $4.75 \mu \mathrm{A} / \mathrm{cm}^{2}$ for the peak-aged specimen in $500 \mathrm{ppm} \mathrm{Cl}^{-}$. In other test conditions and specimens, the passive current densities were in the range of $1.5-2.8 \mu \mathrm{A} / \mathrm{cm}^{2}$. However, the pitting protection potential was influenced by the chloride content and the aging condition.

As discussed earlier, addition of $80 \mathrm{ppm}^{-}$did not affect the stability of the passivity of the EV31A specimens. Increasing the $\mathrm{Cl}^{-}$level to $100 \mathrm{ppm}$ shifted the pitting protection potentials to $1.06,1,37,1.16$ and $1.2 \mathrm{~V}_{\mathrm{Ag} /}$ 

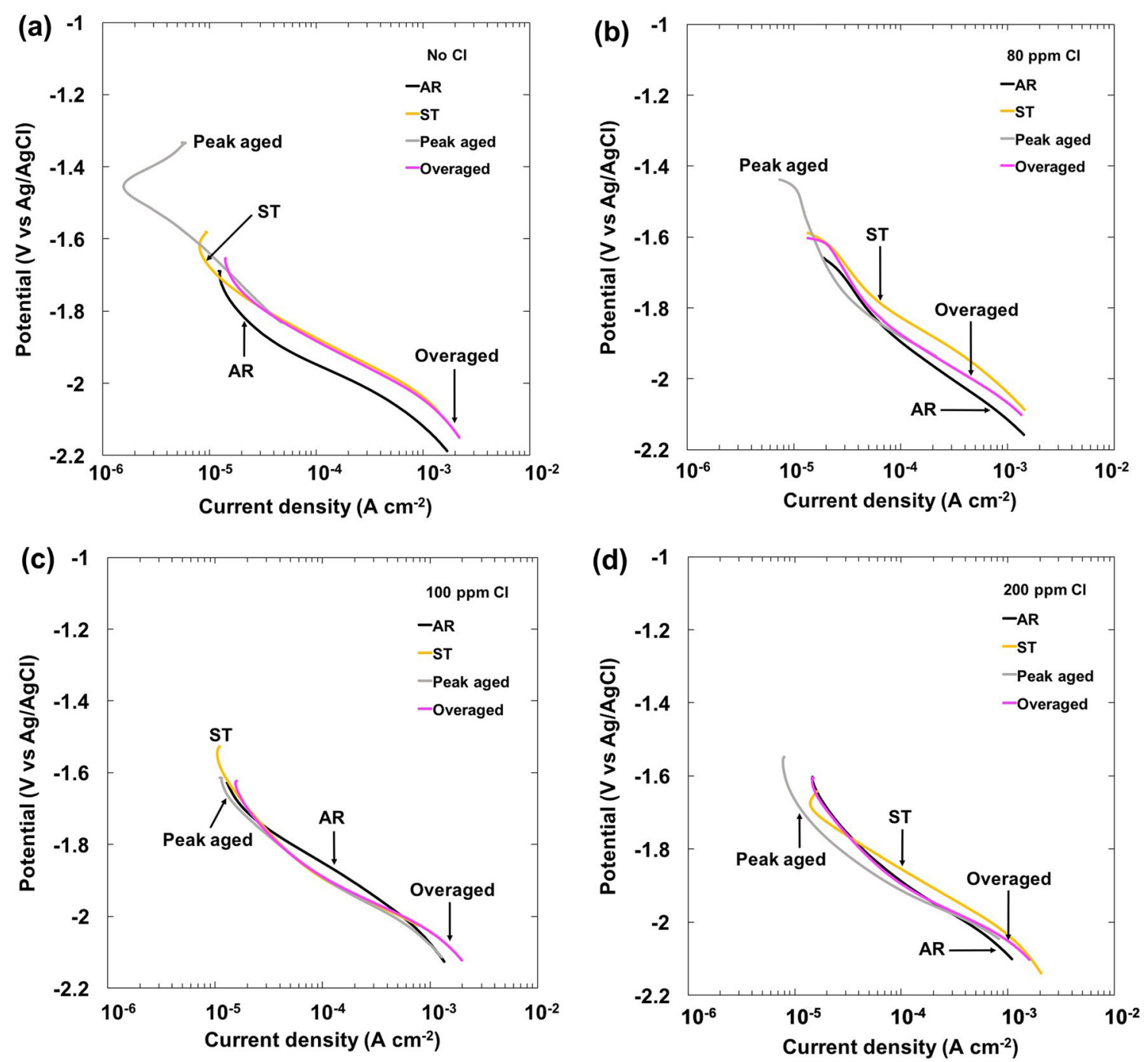

Fig. 4 Cathodic polarization plots of EV31A alloy in different heat-treated conditions in $0.1 \mathrm{M} \mathrm{NaOH}$ solution with different chloride (NaCl) additions: a no chloride addition, b 80 ppm chloride, c 100 ppm chloride, $\mathbf{d} 200$ ppm chloride

$\mathrm{AgCl}$ for the AR, ST, PA and OA specimens, respectively. Increasing $\mathrm{Cl}^{-}$concentration to $200 \mathrm{ppm}$ did not affect the stability of the passive films of AR, ST and PA specimens significantly as observed in Fig. 3d. However, the pitting protection potential of OA specimen decreased to $0.64 \mathrm{~V}_{\mathrm{Ag} /}$

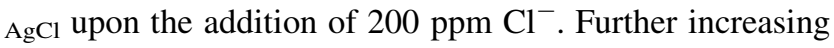
the chloride level to $500 \mathrm{ppm}$ decreased the pitting protection potential of the AR, ST and PA specimens to $-0.02,-0.87$ and 0.59 , respectively. The OA specimen did not repassivate during the reverse scan as observed in Fig. 3e. Increasing the chloride concentration to $1000 \mathrm{ppm}$ caused complete breakdown of the passive film of the specimens during the reverse scan and considerably decreased the transpassive potentials as compared to that of $500 \mathrm{ppm} \mathrm{Cl}^{-}$. The transpassive potentials in $1000 \mathrm{ppm} \mathrm{Cl}^{-}$ solution were $0.48,-0.37,0.18$ and $0.22 \mathrm{~V}_{\mathrm{Ag} / \mathrm{AgCl}}$ for the AR, ST, PA and OA specimens, respectively.
Figure $4 \mathrm{a}-\mathrm{d}$ shows the cathodic polarization plots of EV31A alloy in different heat treatment conditions in $0.1 \mathrm{M} \mathrm{NaOH}$ solution with different chloride $(\mathrm{NaCl})$ additions. Table 3 summarizes the cathodic polarization results. The cathodic reaction is considered to be hydrogen evolution reaction. The equilibrium potential for hydrogen evolution in $\mathrm{pH} 13.5$ solution is about $-1.0 \mathrm{~V}_{\mathrm{Ag} / \mathrm{AgCl}}$. Even though there is not a clear dependence of the hydrogen evolution reaction (HER) kinetics on different heat treatments and different chloride concentrations from Table 3, the following observations can be summarized. (1) The asreceived specimens show lower cathodic reaction kinetics than the other heat treatment conditions in low chloride concentrations. (2) The peak-aged specimens show slower cathodic reaction kinetics in 0 and $100 \mathrm{ppm}$ chloride additions. (3) The Tafel slopes vary from 0.13 to $0.21 \mathrm{~V} /$ decade in general, which indicates that the HER was 
Table 3 Summary of the cathodic polarization results of EV31A alloy in different heat-treated conditions in $0.1 \mathrm{M} \mathrm{NaOH}$ with addition of different chloride concentrations

\begin{tabular}{lllll}
\hline Sample & $\mathrm{Cl}^{-}$concentration & Tafel slope $(\mathrm{V} / \mathrm{dec})$ & $\begin{array}{l}\text { Exchange current density for } \\
\text { hydrogen evolution, } i_{0} \\
\left(\mathrm{~A} / \mathrm{cm}^{2}\right)\end{array}$ & $\begin{array}{l}\text { Over potential for } 1 \mathrm{~mA} / \mathrm{cm}^{2} \\
(\mathrm{~V})\end{array}$ \\
\hline $\mathrm{AR}$ & $\mathrm{No} \mathrm{Cl}^{-}$ & $1.3 \times 10^{-11}$ & -1.11 \\
& $80 \mathrm{ppm}$ & -0.14 & $4.0 \times 10^{-9}$ & -1.11 \\
& $100 \mathrm{ppm}$ & -0.21 & $1.8 \times 10^{-9}$ & -1.07 \\
& $200 \mathrm{ppm}$ & -0.18 & $9.0 \times 10^{-10}$ & -1.08 \\
$\mathrm{ST}$ & $\mathrm{No} \mathrm{Cl}$ & -0.18 & $2.9 \times 10^{-10}$ & -1.03 \\
& $80 \mathrm{ppm}$ & -0.16 & $2.4 \times 10^{-9}$ & -1.04 \\
& $100 \mathrm{ppm}$ & -0.18 & $1.3 \times 10^{-10}$ & -1.03 \\
& $200 \mathrm{ppm}$ & -0.14 & $7.0 \times 10^{-10}$ & -1.25 \\
Peak aged & $\mathrm{No} \mathrm{Cl}$ & -0.18 & $4.0 \times 10^{-9}$ & -1.05 \\
& $80 \mathrm{ppm}$ & -0.19 & $3.8 \times 10^{-10}$ & -1.07 \\
& $100 \mathrm{ppm}$ & -0.18 & $1.5 \times 10^{-10}$ & -1.05 \\
& $200 \mathrm{ppm}$ & -0.16 & $1.2 \times 10^{-11}$ & -1.04 \\
Overaged & $\mathrm{No} \mathrm{Cl}$ & -0.13 & $5.5 \times 10^{-10}$ & -1.07 \\
& $80 \mathrm{ppm}$ & -0.17 & $7.7 \times 10^{-10}$ & -1.04 \\
& $100 \mathrm{ppm}$ & -0.18 & $1.0 \times 10^{-10}$ & -1.05 \\
\hline
\end{tabular}

controlled by Volmer reaction: $M+\mathrm{H}_{2} \mathrm{O}+\mathrm{e}^{-} \rightarrow-$ $M \mathrm{H}+\mathrm{OH}^{-}$[41], followed by Tafel reaction: $M \mathrm{H}+M \mathrm{H} \rightarrow 2 M+\mathrm{H}_{2} \uparrow$, where $M$ denotes metal active site for hydrogen adsorption. The polarization plots indicate that the exchange current density for hydrogen evolution is very low in the range of $\mathrm{pA} / \mathrm{cm}^{2}$ to $\mathrm{nA} / \mathrm{cm}^{2}$. Song et al. [42] reported an exchange current density in the range of 5-7 $\mathrm{pA} / \mathrm{cm}^{2}$ for $\mathrm{Mg}$ in $\mathrm{pH} 13 \mathrm{Na}_{2} \mathrm{SO}_{4}$ solution and a Tafel slope of $260 \mathrm{mV} / \mathrm{dec}$ ade. On the other hand, Frankel et al. [43] reported a very high Tafel slope of $0.75 \mathrm{~V} /$ decade and an exchange current density of $4 \mu \mathrm{A} / \mathrm{cm}^{2}$ for $\mathrm{Mg}$ in neutral $\mathrm{NaCl}$ solution. The high exchange current density of $\mathrm{Mg}$ in chloride solution could possibly be attributed to enhanced surface area due to dissolution of $\mathrm{Mg}$. In high $\mathrm{pH}$ solutions, not only passivation is induced on $\mathrm{Mg}$ alloys but also the rate of cathodic hydrogen evolution reaction is lower. Birbilis and coworkers [44] reported enhanced hydrogen evolution on $\mathrm{Mg}(\mathrm{OH})_{2}$-covered $\mathrm{Mg}$ surfaces. The rate of HER on the $\mathrm{Mg}(\mathrm{OH})_{2}$ was 4-6 times faster than that of the pristine $\mathrm{Mg}$ surface at -1.9 $\mathrm{V}_{\mathrm{SCE}}$ in $\mathrm{pH} 11$ solution. The higher activity of HER on the hydroxide-covered surface was attributed to the enhanced self-dissociation of the water. On the other hand, Song and Unocic [28] argued that the presence of an oxide/hydroxide film which is electronically insulating would slow down the HER kinetics due to increased electrical resistivity of the surface films as compared to the bare Mg surface. In the absence of any surface analysis data, it is not possible to discuss how the surface film of the EV31A alloy affected the HER kinetics.

\subsection{Potentiostatic Passivation}

Figure 5a-e shows the $I-t$ plots in log-log scale of the specimens in different chloride-containing solutions under potentiostatic conditions. The applied potential is in the middle of the passivation range of individual specimens based on their polarization curves shown in Fig. 3. Typically this potential is around $0.5 \mathrm{~V}_{\mathrm{Ag} / \mathrm{AgCl}}$. The anodic current density decayed almost linearly in the log-log scale. The passive current decay could be represented using the equation:

$I=I_{0} t^{-a}$,

where $I$ is passivation current at time $t, I_{0}$ is initial current density of the fresh specimen surface in the test environment, $\alpha$ is passivation kinetic exponent [45]. The value of $\alpha$ gives an idea about how quickly the surface can be passivated in a given environment. Higher the value of the $\alpha$, faster is the passivation kinetics and better the microstructural condition. Negative values of $\alpha$ indicate that the current increases with time and there is passivity breakdown. Using this approach, different heat treatment conditions of the EV31A can be evaluated in $0.1 \mathrm{M} \mathrm{NaOH}$ solution with different chloride concentrations. The passivation kinetic exponent values are summarized in Table 4. 

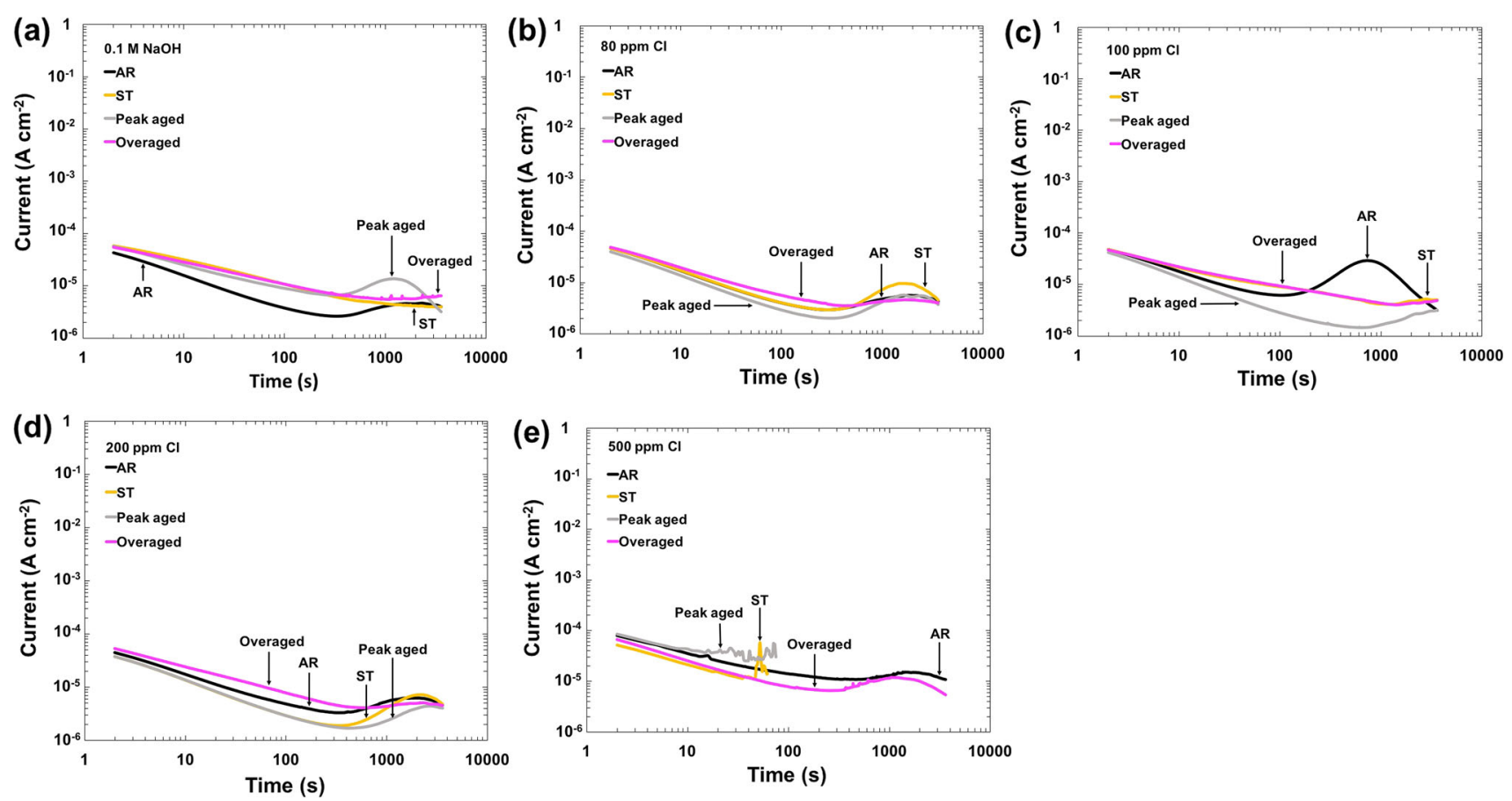

Fig. $5 I-t$ plots of EV31A specimens with different heat treatment conditions under potentiostatic control in $0.1 \mathrm{M}$ NaOH solution with different chloride additions: a no chloride, $\mathbf{b} 80 \mathrm{ppm} \mathrm{Cl}^{-} \mathbf{c} 100 \mathrm{ppm} \mathrm{Cl}^{-}, \mathbf{d} 200 \mathrm{ppm} \mathrm{Cl}^{-}$, e $500 \mathrm{ppm} \mathrm{Cl}^{-}$. The applied potential (typically $\left.0.5 \mathrm{~V}_{\mathrm{Ag} / \mathrm{AgCl}}\right)$ was in the middle of the passivation range of the corresponding heat-treated condition as shown in Fig. 3

Table 4 Passivation kinetic exponent and charge carrier density of EV31A specimens in different heat-treated conditions in different concentrations of chloride

\begin{tabular}{|c|c|c|c|}
\hline Sample & $\mathrm{Cl}^{-}$concentration & $\begin{array}{l}\text { Passivation } \\
\text { kinetic exponent } \\
\alpha\end{array}$ & $\begin{array}{l}\text { Charge carrier } \\
\text { density, } N_{\mathrm{D}} \\
\left(1 / \mathrm{cm}^{3}\right)\end{array}$ \\
\hline \multirow[t]{3}{*}{$\mathrm{AR}$} & $\mathrm{No} \mathrm{Cl}^{-}$ & 0.684 & $2.08 \times 10^{21}$ \\
\hline & $80 \mathrm{ppm}$ & 0.687 & $2.46 \times 10^{21}$ \\
\hline & $500 \mathrm{ppm}$ & 0.55 & $5.42 \times 10^{21}$ \\
\hline \multirow[t]{3}{*}{ ST } & No $\mathrm{Cl}^{-}$ & 0.46 & $1.29 \times 10^{21}$ \\
\hline & $80 \mathrm{ppm}$ & 0.68 & $3.54 \times 10^{21}$ \\
\hline & $500 \mathrm{ppm}$ & 0.57 & N/A \\
\hline \multirow[t]{3}{*}{ Peak aged } & $\mathrm{No} \mathrm{Cl}^{-}$ & 0.48 & $3.50 \times 10^{21}$ \\
\hline & $80 \mathrm{ppm}$ & 0.72 & $2.30 \times 10^{21}$ \\
\hline & $500 \mathrm{ppm}$ & 0.47 & N/A \\
\hline \multirow[t]{3}{*}{ Overaged } & $\mathrm{No} \mathrm{Cl}^{-}$ & 0.42 & $1.87 \times 10^{21}$ \\
\hline & $80 \mathrm{ppm}$ & 0.59 & $2.50 \times 10^{21}$ \\
\hline & $500 \mathrm{ppm}$ & 0.55 & $5.49 \times 10^{21}$ \\
\hline
\end{tabular}

In the absence of chloride, from Fig. 5a it can be seen that the AR specimen showed the fastest passivation kinetics during the first $100 \mathrm{~s}$ of passivation. This fast kinetics could be attributed to the textured microstructure, finer grain size and possibly high dislocation density of the AR specimen that promote fast diffusion of reactive elements through the short circuits of grain boundaries and dislocation channels. After reaching the lowest current density of about $2 \mu \mathrm{A} / \mathrm{cm}^{2}$, the current starts to increase which could be due to dissolution of secondary phases or regions adjacent to the secondary phases.

The ST, PA and OA specimens exhibited more or less a similar passivation kinetics behavior in $0.1 \mathrm{M} \mathrm{NaOH}$. Interestingly, the peak-aged specimen showed an increase in the current after $300 \mathrm{~s}$ of passivation and decay in current density after $1000 \mathrm{~s}$. With the addition of chloride, it can be observed that the peak-aged specimen showed faster repassivation kinetics than any other heat-treated specimens, and the overaged specimen exhibited slower passivation kinetics.

Figure 6a-d illustrates the location of pit initiation in the specimens exposed to $500 \mathrm{ppm} \mathrm{Cl}^{-}+0.1 \mathrm{M} \mathrm{NaOH}$ under potentiostatic control at $1.1 \mathrm{~V}_{\mathrm{Ag} / \mathrm{AgCl}}$. The pit initiation predominantly occurred within the secondary phase particles in all the heat treatment conditions, as shown in Fig. 6a-d. Particles with spherical morphology were more susceptible to localized dissolution than other morphologies. Dissolution is observed to start at the center of the spherical particle. The overaged specimen showed pit initiation at the interface between the secondary phase and the solid solution matrix as shown in Fig. 6d. In this case, the particle had an irregular shape. In all the specimens, the spherical particles were observed to be enriched in $\mathrm{Zr}$ and Fe based on the scanning electron microscopy/energy-dispersive X-ray (SEM/EDX) analyses. The selective attack could be attributed to dissolution of $\mathrm{Zr}$ in strong alkaline 

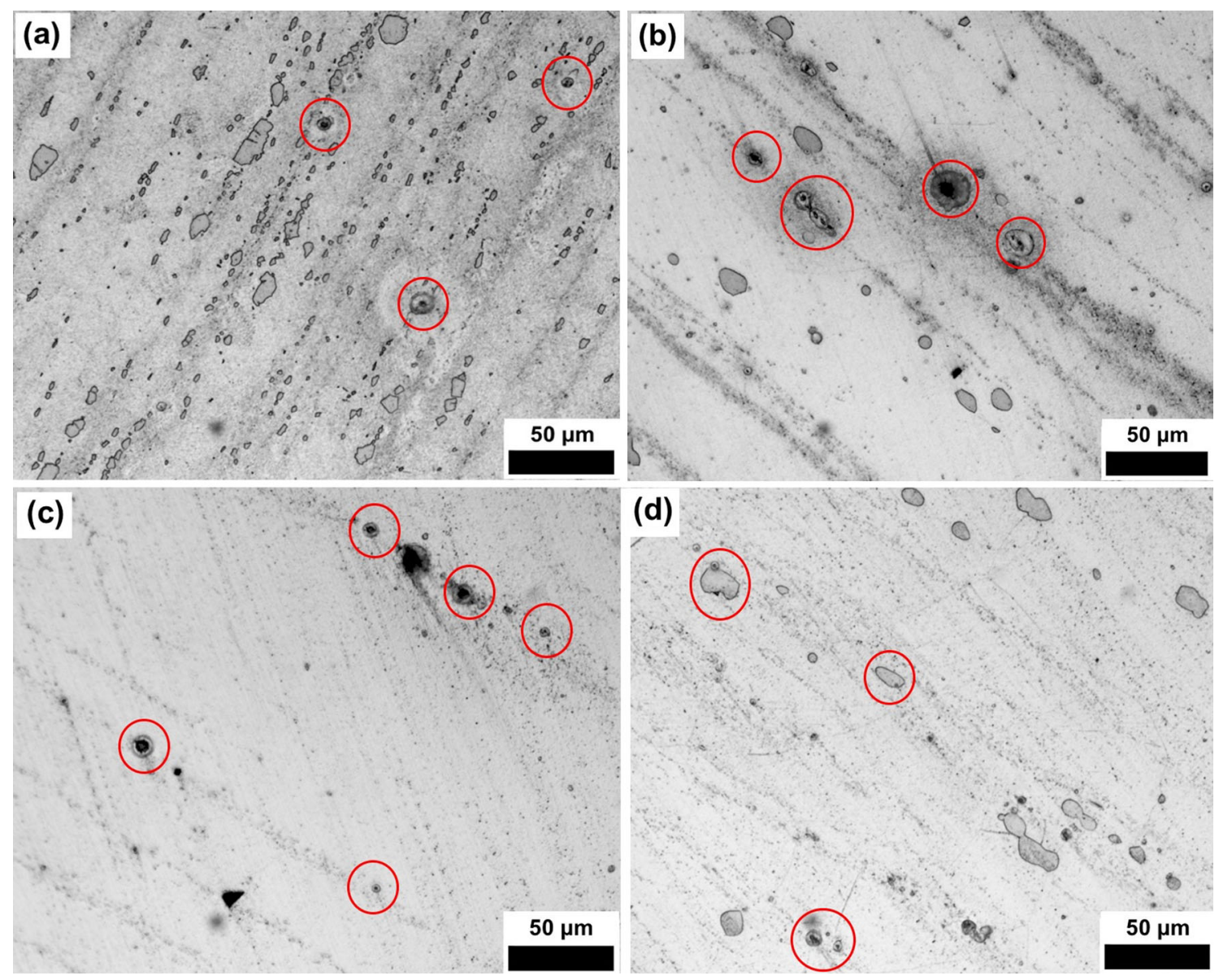

Fig. 6 Optical microstructures of the specimens under potentiostatic condition $\left(1.1 \mathrm{~V}_{\mathrm{Ag} / \mathrm{AgCl}}\right)$ until pit initiation in $500 \mathrm{ppm} \mathrm{Cl}^{-}+0.1 \mathrm{M}$ $\mathrm{NaOH}$ : a as-received, b solution heat-treated, c peak-aged $\left(200{ }^{\circ} \mathrm{C}, 16 \mathrm{~h}\right), \mathbf{d}$ overaged $\left(200{ }^{\circ} \mathrm{C}, 100 \mathrm{~h}\right)$

solutions. The particles that were not attacked represented a composition of $\mathrm{Mg}_{3} \mathrm{RE}$. The irregular-shaped particles in the OA specimen that exhibited attack at the interface are enriched in $\mathrm{Nd}$ and $\mathrm{Zn}$. Figure 7a, b shows typical SEM images of the surface before and after corrosion testing. The typical energy-dispersive X-ray analyses of the secondary phase particles are shown in Fig. 7c, d. The particle circled in Fig. 7a could be identified as $\mathrm{Mg}_{3} \mathrm{RE}$ phase, and the elongated particle circled in Fig. $7 \mathrm{~b}$ could possibly be labeled as a mixture of $\mathrm{Mg}_{7} \mathrm{Zn}_{3}$ and $\mathrm{Mg}_{5} \mathrm{Nd}$.

The results of AC impedance spectroscopy are illustrated in Fig. 8a-d as Nyquist plots. The EIS measurements were carried out after passivating the specimens by applying a constant potential that was in the middle of the passivation range of the anodic polarization curve. The specimens were passivated for $1 \mathrm{~h}$ before running the EIS, and thus, the specimens might have only reached their quasi-steady states. Since the EIS data do not represent the steady-state conditions, the following analyses of the different heat treatment conditions are simply for comparative purpose.
In the $0.1 \mathrm{M} \mathrm{NaOH}$ without chloride addition, the overaged specimens showed the lowest magnitude of impedance spectrum among the investigated conditions, and the ST specimen showed the highest impedance spectrum. This trend more or less reversed with the addition of $80 \mathrm{ppm}$ chloride. The impedance results could be correlated with the recorded passivation current densities of the respective specimens but not with the pitting protection potentials. The peak-aged specimens showed higher impedance spectra in 80, 100 and $200 \mathrm{ppm} \mathrm{Cl}^{-}$-containing solutions than the other heat-treated specimens.

The impedance data were initially fitted with different combinations of equivalent circuit elements to select a right model that gave the best fit with a low Chi-square value. Pinto et al. [32] fitted the EIS data of $\mathrm{Mg}-\mathrm{Zr}$ alloys in $\mathrm{pH}$ 13 using Voigt circuit that contained 2-parallel RC loops connected in series with another resistor. When the same alloys were passivated in borated buffer solution, Pinto et al. [33] used 3-RC loops connected in series with one RC loop containing an inductor to account for the relaxation phenomena on the electrode surface. Such relaxation occurred at low frequencies and was related to the adsorbed 

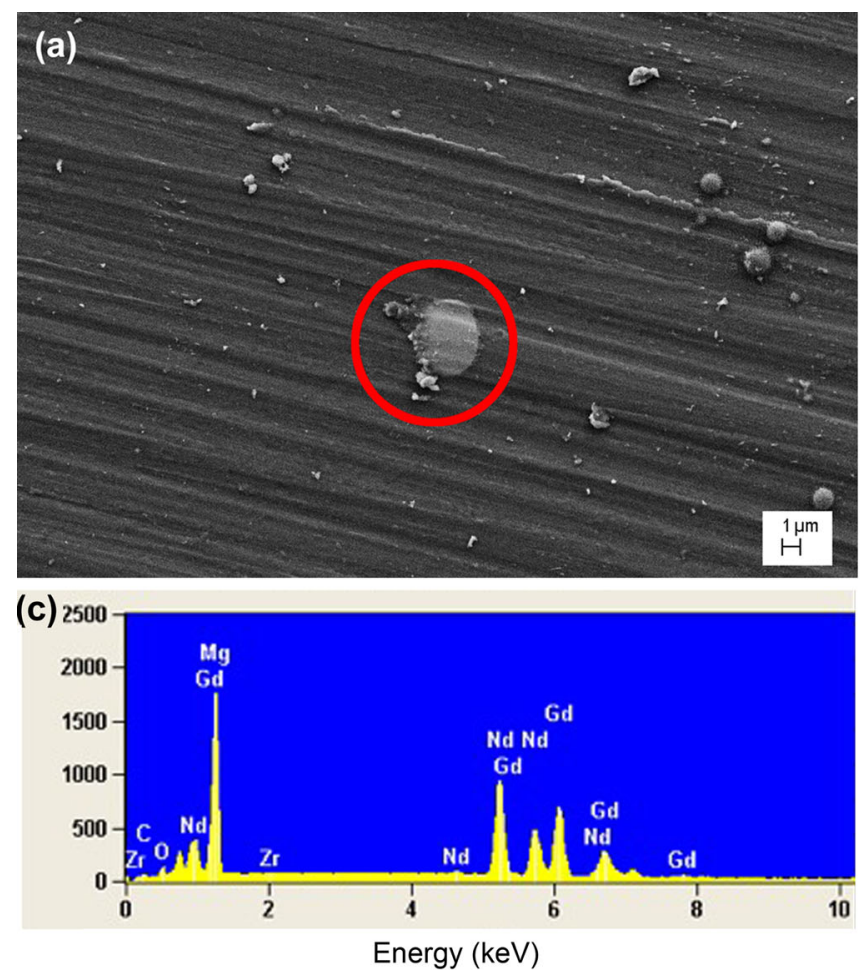
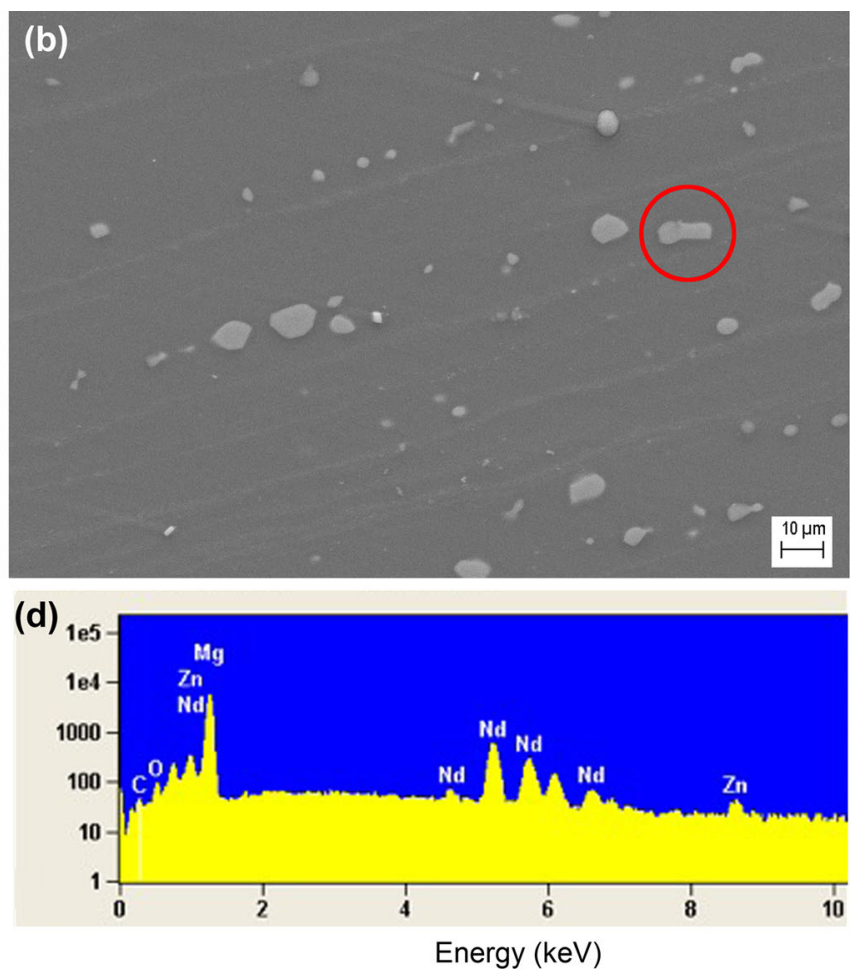

Fig. $7 \mathrm{SEM}$ images of the solution heat-treated specimen before and after $1 \mathrm{~h}$ potentiostatic passivation at $0.5 \mathrm{~V} \mathrm{Vg}_{\mathrm{AgCl}}$ in $0.1 \mathrm{M} \mathrm{NaOH}$ solution: $\mathbf{a}$ before the test, $\mathbf{b}$ after the test, $\mathbf{c}$ EDX spectrum of elemental analysis of the circled particle in $\mathbf{a}$, and $\mathbf{d}$ EDX spectrum of the circled particle shown in b. Noted that the specimen in Fig. 7a was ground with SiC paper up to 600 grit, and specimen in Fig. $7 \mathrm{~b}$ was ground up to $1-\mu \mathrm{m}$ diamond suspension. The images do not show the exact same area

$\mathrm{Mg}^{+}$reacting to $\mathrm{Mg}^{2+}$ or $\mathrm{MgOH}^{+}$species as proposed by Baril et al. [46] and Anik and Celikten [47]. The presence of $\mathrm{Mg}^{+}$ions has been disputed by other researchers [48], and Song et al. [49] attributed the inductive loop to the corrosion attack of the substrate. It should be noted that no inductive loops were recorded on any of the specimens in $0.1 \mathrm{M} \mathrm{NaOH}$ with or without chloride additions in this investigation.

Among different electrical equivalent circuits tried, the one illustrated in Fig. 8e fitted the data with $\chi^{2}<10^{-4}$. This equivalent circuit is more or less similar to the one proposed by Song [50] for concrete structures. In this equivalent circuit, $R_{\mathrm{s}}$ represents the electrolyte resistance, $R_{1}$ is associated with the charge transfer resistance, $Q_{1}$ (a constant phase element) is related to the electrode/electrolyte interfacial capacitance, $R_{2}$ is the resistance introduced by $\mathrm{RE}$ oxide/hydroxide incorporated in the $\mathrm{MgO} /$ $\mathrm{Mg}(\mathrm{OH})_{2}$ surface layer, and $Q_{2}$ is the capacitance due to the surface layer space charge. The $Q_{1}$ and $Q_{2}$ are leaky capacitors with distributed time constants due to surface heterogeneity.

Table 5 summarizes the equivalent circuit values of the specimens in different chloride concentrations. The solution resistance values do not change significantly with the heat treatment condition and chloride addition. The values of $Q_{1}$ also are more or less similar among the test conditions. Significant variations are the $Q_{2}$ values that represented the passive layer conditions. A higher value of $Q_{2}$ indicates a more defective film that is less protective. The admittance values increase in general with increasing chloride concentration. The $R_{1}$ values associated with charge transfer resistance are large for the peak-aged and overaged specimens as summarized in Table 5. However, the $R_{1}$ value decreases significantly for the overaged specimen in the $500 \mathrm{ppm} \mathrm{Cl}^{-}$solution. Most of the values of $R_{2}$ do not change considerably with heat treatment or chloride additions. These results indicate that the passivation behavior is determined more by the capacitance values than by the resistance values of the passive layer. The semiconducting behavior of the passive layer is illustrated by Mott-Schottky plots. Figure 9 shows the Mott-Schottky plots of the overaged specimen in different chloride concentrations. Other heat-treated specimens also show a similar trend of Mott-Schottky behavior. The positive slopes of the $1 / C^{2}$ vs potential plots indicate the $n$-type semiconducting nature of the passive layers. The charge carrier density values are summarized in Table 4 . The charge carriers can be ascribed as ionic point defects such as oxygen vacancies or cation (such as $\mathrm{Mg}^{2+}, \mathrm{Nd}^{3+}, \mathrm{Gd}^{3+}$, $\mathrm{Zn}^{2+}$ ) interstitials. The defect density increases with 

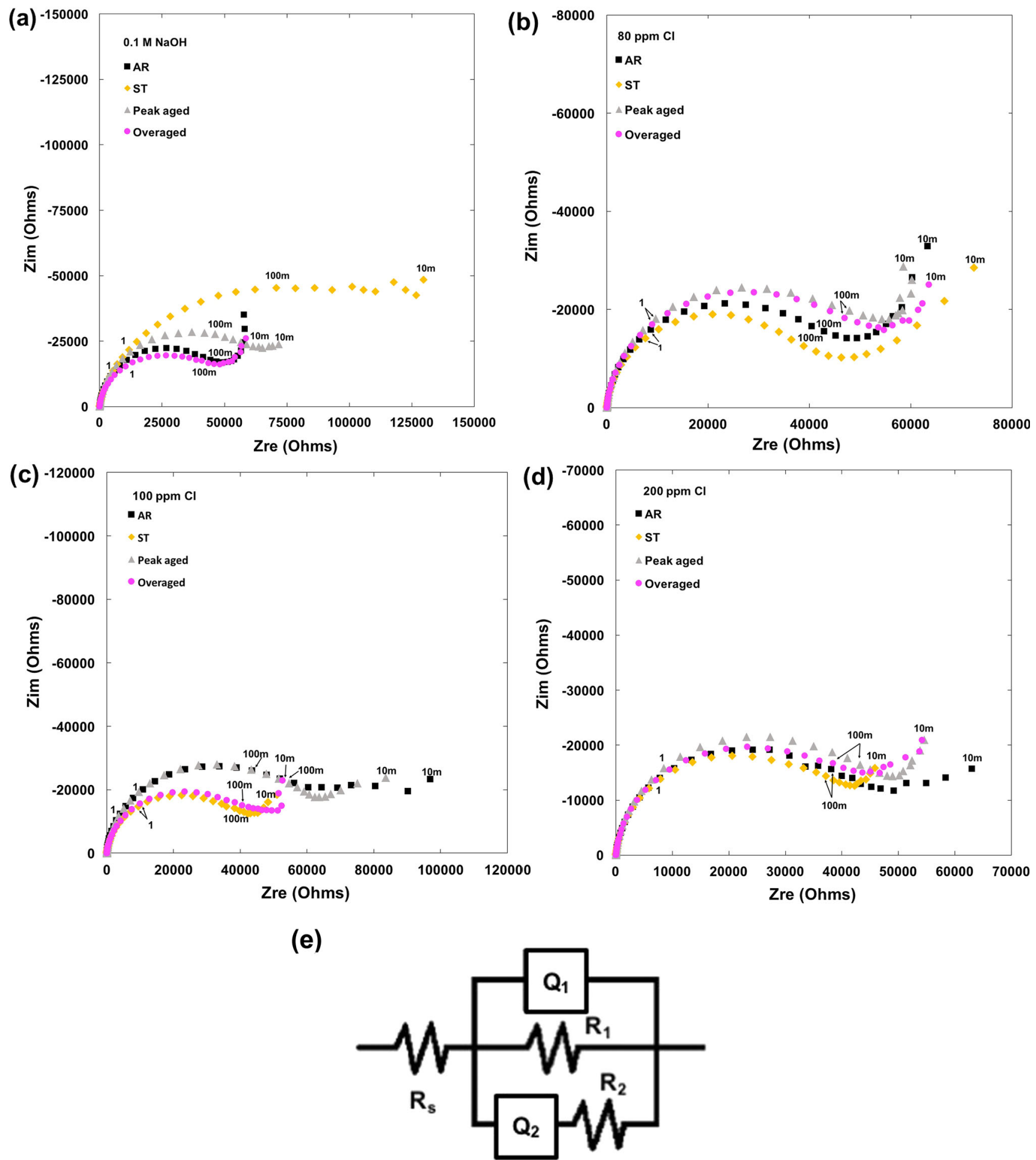

Fig. 8 Nyquist plots of EV31A specimens passivated at mid-potential of their passivation ranges for $1 \mathrm{~h}$ in $0.1 \mathrm{M} \mathrm{NaOH}$ solution with different

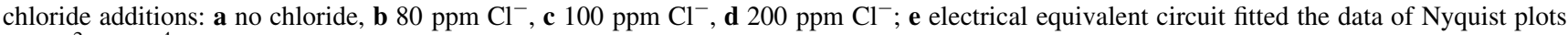
with $\chi^{2}<10^{-4}$

increasing chloride content of the electrolyte for a given heat treatment condition except for the peak-aged condition. The ST and OA specimens show passive layers with lower charge carrier densities in $0.1 \mathrm{M} \mathrm{NaOH}$ without chloride condition. The increase in defect density with increasing chloride concentration of electrolyte could be correlated with the susceptibility of the OA specimen to localized corrosion. 
Table 5 Equivalent circuit values of the specimens in different chloride concentrations

\begin{tabular}{lclllllll}
\hline Sample & $\begin{array}{l}\mathrm{Cl}^{-} \text {concentration } \\
(\mathrm{ppm})\end{array}$ & $\begin{array}{l}R_{\mathrm{s}} \\
(\mathrm{Ohm})\end{array}$ & $\begin{array}{l}Q_{1} \\
\left(\mathrm{~S} \cdot \mathrm{s}^{\alpha}\right)\end{array}$ & $\alpha$ & $\begin{array}{l}Q_{2} \\
\left(\mathrm{~S} \cdot \mathrm{s}^{\beta}\right)\end{array}$ & $\beta$ & $\begin{array}{l}R_{1} \\
(\mathrm{Ohm})\end{array}$ \\
\hline AR & 0 & 51.59 & $9.063 \times 10^{-6}$ & 0.8 & $2.084 \times 10^{-4}$ & 0.8 & $\begin{array}{l}R_{2} \\
(\mathrm{Ohm})\end{array}$ \\
& 80 & 53.31 & $8.449 \times 10^{-6}$ & 0.9441 & $1.616 \times 10^{-4}$ & 0.5918 & $8.461 \times 10^{11}$ & $4.956 \times 10^{4}$ \\
& 500 & 55.41 & $9.759 \times 10^{-6}$ & 0.9475 & $2.536 \times 10^{-5}$ & 0.7867 & $4.933 \times 10^{4}$ & $1.011 \times 10^{5}$ \\
ST & 0 & 58.7 & $5.65 \times 10^{-6}$ & 0.9218 & $8.943 \times 10^{-6}$ & 0.2355 & $4.511 \times 10^{5}$ & $9.939 \times 10^{-4}$ \\
& 80 & 50.77 & $9.583 \times 10^{-6}$ & 0.9475 & $5.216 \times 10^{-5}$ & 0.8719 & $8.237 \times 10^{4}$ & $9.312 \times 10^{4}$ \\
& 500 & - & - & - & - & - & - & - \\
Peak aged & 0 & $5.84 \times 10^{-16}$ & $1.393 \times 10^{-5}$ & $2.96 \times 10^{-10}$ & $1.313 \times 10^{-5}$ & 0.9162 & $2.274 \times 10^{12}$ & 56.36 \\
& 80 & 63.1 & $7.567 \times 10^{-6}$ & 0.9459 & $2.414 \times 10^{-4}$ & 0.7426 & $6.31 \times 10^{13}$ & $5.434 \times 10^{4}$ \\
& 500 & - & - & - & - & - & - \\
& 0 & 48.64 & $7.823 \times 10^{-6}$ & 0.9255 & $8.999 \times 10^{-7}$ & 0.4205 & $5.732 \times 10^{13}$ & $3.668 \times 10^{4}$ \\
& 80 & 51.18 & $8.189 \times 10^{-6}$ & 0.9384 & $1.664 \times 10^{-4}$ & 0.5575 & $1.353 \times 10^{18}$ & $4.977 \times 10^{4}$ \\
& 500 & 49.46 & $1.055 \times 10^{-5}$ & 0.9494 & $3.477 \times 10^{-5}$ & 0.6005 & $8.024 \times 10^{4}$ & $1.009 \times 10^{5}$ \\
\hline
\end{tabular}

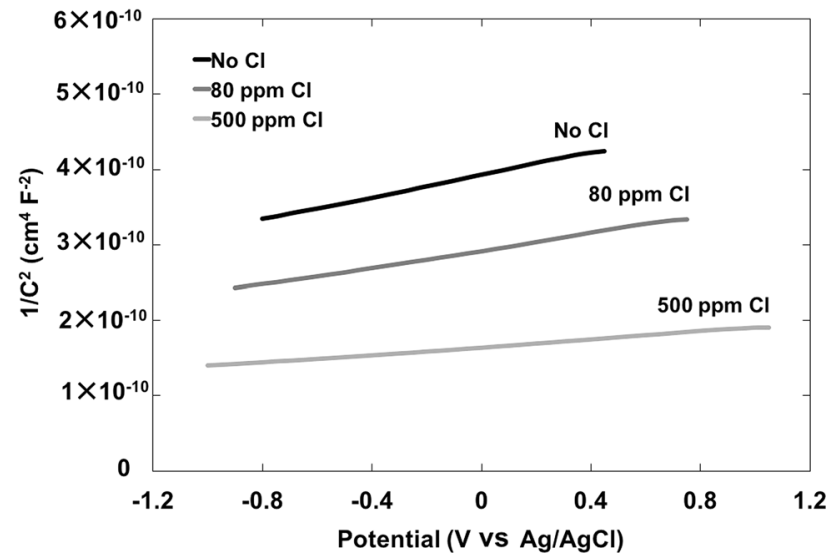

Fig. 9 Mott-Schottky plots of overaged $\left(200{ }^{\circ} \mathrm{C}\right.$ for $\left.100 \mathrm{~h}\right)$ specimen in solution with different chloride concentrations

\section{Conclusions}

1. Polarization of the specimens to transpassive potentials $\left(>1.6 \mathrm{~V}_{\mathrm{Ag} / \mathrm{AgCl}}\right)$ introduced defects in the passive layers and possibly changed the surface area by dissolution of active elements. Therefore, a small hysteresis could be observed even in the absence of chloride during the reverse scan of the cyclic polarization.

2. No passivity breakdown was observed up to $80 \mathrm{ppm}$ chloride addition for specimens with any heat treatments.

3. The pitting protection potentials of the solution heattreated and peak-aged specimens remained high at about $1.1 \mathrm{~V}_{\mathrm{Ag} / \mathrm{AgCl}}$ in the basic solution $0.1 \mathrm{M} \mathrm{NaOH}$ containing up to $200 \mathrm{ppm}$ chloride addition.

4. Significant reduction in pitting protection potentials was observed with $500 \mathrm{ppm}$ chloride addition and a
1000 ppm chloride addition caused complete passivity breakdown for all the specimens with different heat treatments.

5. Overall, the peak-aged $\left(200{ }^{\circ} \mathrm{C}, 16 \mathrm{~h}\right)$ specimen showed better corrosion resistance than specimens with any other heat treatments.

Acknowledgements The support provided by the US Nuclear Regulatory Commission through a faculty development grant NRC-HQ84-15-G-0025 is gratefully acknowledged. J. Ninlachart acknowledges the support by Royal Thai Navy.

\section{References}

[1] Y. Huang, W. Gan, K.U. Kainer, N. Hort, J. Magnes, Alloys 2, 1 (2014)

[2] N. Stanford, D. Atwell, A. Beer, C. Davies, M.R. Barnett, Scripta Mater. 59, 772 (2008)

[3] G.L. Makar, J. Kruger, Int. Met. Rev. 38, 138 (1993)

[4] L.L. Rokhlin, Mg Alloys Containing RE Metals (Taylor and Francis, London, 2003)

[5] Z.L. Ning, H. Wang, H.H. Liu, F.Y. Cao, S.T. Wang, J.F. Sun, Mater. Des. 31, 4438 (2010)

[6] G. Riontino, D. Lussana, M. Massazza, G. Barucca, P. Mengucci, R. Ferragut, J. Alloys Compd. 463, 200 (2008)

[7] Elektron 21 Data sheet: 455, Magnesium Elektron UK (2006)

[8] R. Arroyave, D. Shin, Z.K. Liu, Calphad 29, 230 (2005)

[9] S. Bhan, A. Lal, J. Phase Equilib. 14, 634 (1993)

[10] P.H. Fu, L.M. Peng, H.Y. Jiang, C.Q. Zhai, X. Gao, J.F. Nie, Mater. Sci. Forum 97, 546 (2007)

[11] A.A. Nayeb-Hashemi, J.B. Clark, The Mg-Nd system. Bull. Alloy Phase Diagrams 9, 618 (1988)

[12] S. Delfino, A. Saccone, R. Ferro, Metal. Trans. A 21, 2109 (1990)

[13] P. Lyon, T. Wilks, I. Syed, ed. by N.R. Neelameggham, H.I. Kaplan, B.R. Powell, Magnes. Technol 2005. TMS 303 (2005)

[14] J.F. Nie, X. Gao, S.M. Zhu, Scripta Mater. 53, 1049 (2005) 
[15] A. Kielbus, T. Rzychon, R. Przeliorz, Mater. Sci. Forum 638-642, 1447 (2010)

[16] A. Kielbus, T. Rzychon, L. Litynska-Dobrzynska, G. Dercz, Solid State Phenom. 163, 106 (2010)

[17] D.H. Ping, K. Hono, J.F. Nie, Scripta Mater. 48, 1017 (2003)

[18] L.R. Gill, G.W. Lorimer, P. Lyon, Adv. Eng. Mater. 9, 784 (2007)

[19] G. Williams, K. Gusieva, N. Birbilis, Corros. (NACE) 68, 489 (2012)

[20] P. Maier, R. Peters, C.L. Mendis, S. Muller, N. Hort, JOM 68, 1183 (2016)

[21] T. Cain, L.G. Bland, N. Birbilis, J.R. Scully, Corros. (NACE) 70, 1043 (2014)

[22] A.D. Sudholz, N.T. Kirkland, R.G. Buchheit, N. Birbilis, Electrochem. Solid-State Lett. 14, C5 (2011)

[23] F. Czerwinski, Int. Mater. Rev. 60, 264 (2015)

[24] X. Xia, J.F. Nie, C.H.J. Davies, W.N. Tang, S.W. Xu, N. Birbilis, Corros. (NACE) 71, 1370 (2015)

[25] K.M. Ismail, S. Virtanen, Electrochem. Solid State Lett. 10, C9 (2007)

[26] M. Taheri, J.R. Kish, J. Electrochem. Soc. 160, C36 (2013)

[27] S. Li, A.C. Bacco, N. Birbilis, H. Cong, Corros. Sci. 112, 596 (2016)

[28] G.L. Song, K.A. Unocic, Corros. Sci. 98, 758 (2015)

[29] F. Cao, G.L. Song, A. Atrens, Corros. Sci. 111, 835 (2016)

[30] G.L. Song, K.A. Unocic, M. Harry III, E. Cakmak, M.P. Brady, P.E. Gannon, P. Himmer, Q. Andrews, Corros. Sci. 104, 36 (2016)

[31] H.B. Yao, Y. Li, A.T.S. Wee, Electrochim. Acta 48, 4197 (2003)

[32] R. Pinto, M.G.S. Ferreira, M.J. Carmezim, M.F. Montemor, Electrochim. Acta 55, 2482 (2010)
[33] R. Pinto, M.G.S. Ferreira, M.J. Carmezim, M.F. Montemor, Electrochim. Acta 56, 1535 (2011)

[34] M. Pourbaix, Atlas of Electrochemical Equilibria in Aqueous Solutions (NACE International, CEBELCOR, Houston Texas, Brussels, 1974), pp. 139-145

[35] D. Wu, Y.Q. Ma, R.S. Chen, W. Ke, J. Magnes, Alloys 2, 20 (2014)

[36] D.A. Jones, Principles and Prevention of Corrosion, 2nd edn. (Prentice-Hall, New Jersey, 1996)

[37] P.W. Chu, E.A. Marquis, Corros. Sci. 101, 94 (2015)

[38] K.S. Raja, D.A. Jones, Corros. Sci. 48, 1623 (2005)

[39] M. Pourbaix, Atlas of electrochemical equilibria in aqueous solutions NACE 197 (1974)

[40] M.G.L.-B. Natta, Corrosion 57, 714 (2001)

[41] E. Gileadi, Physical Electrochemistry (Wiley-VCH, Weinheim, 2011), pp. 98-99

[42] G. Song, A. Atrens, D. St. John, X. Wu, J. Nairn, Corros. Sci. 39, 1981 (1997)

[43] G.S. Frankel, A. Samaniego, N. Birbilis, Corros. Sci. 70, 104 (2013)

[44] S.H. Salleh, S. Thomas, J.A. Yuwono, K. Venkatesan, N. Birbilis, Electrochim. Acta 161, 144 (2015)

[45] G.T. Burstein, D.H. Davies, J. Electrochem. Soc. 128, 33 (1981)

[46] G. Baril, G. Galicia, C. Deslouis, N. Pebere, B. Tribollet, V. Vivier, J. Electrochem. Soc. 154, C108 (2007)

[47] M. Anik, G. Celikten, Corros. Sci. 49, 1878 (2007)

[48] S. Thomas, N.V. Madhekar, G.S. Frankel, N. Birbilis, Curr. Opin. Solid State Mater. Sci. 19, 85 (2015)

[49] Y. Song, E.H. Han, K. Dong, D. Shan, C.D. Yim, B.S. You, Corros. Sci. 88, 215 (2014)

[50] G.L. Song, Cem. Concr. Res. 30, 1723 (2000) 